\title{
On-line Science Learning During the Pandemic COVID-19 and Its Related Problems
}

\author{
Eka Murdani* \\ Doctorate Student of Science Education \\ Universitas Pendidikan Indonesia \\ Bandung, Indonesia \\ *ekamurdani@upi.edu
}

\author{
Anna Permanasari \\ Science Education Program, Post-Graduate Studies \\ Universitas Pendidikan Indonesia \\ Bandung, Indonesia \\ anna.permanasari@upi.edu
}

\author{
Andi Suhandi \\ Department of Physics Education, Post-Graduate School \\ Universitas Pendidikan Indonesia \\ Bandung, Indonesia \\ andi-sh@upi.edu
}

\begin{abstract}
The Covid-19 outbreak has caused a paradigm shift in learning at all levels of Education in Indonesia and other countries in the world. During learning from home, everyone is forced to do learning within a network. Survey research has been carried out to portray the implementation of government policy related to the curriculum in Covid-19 period, with a focus on science learning at secondary school level. The respondent were 97 students and 10 science teachers carrying out learning form home (LFH). The questionnaires were made for student and teacher and distributed through Google Form. The research shows that the online science learning was mostly conducted via WhatsApp as a main learning media. Video streaming media such as video meeting was not often used due to the limited internet quota. Teachers had conducted meaningful science learning that attributed life skills on how to avoid the Covid-19 contagion, and more than $\mathbf{9 0 \%}$ indicators of learning had been achieved by student. In Student opinion, only a half of science learning provided activities suitable to the student interests. Additionally, most of learning (97\%) only gave multiple-choice assignments for practice. However, online learning was still demanded by student and they actively participated in learning $(\mathbf{8 8 . 7 \%})$. Nevertheless, not all of student were happy with the online learning due to the difficulties in understanding the subject $(69.1 \%)$, the difficulties in finalizing the task $(61.9 \%)$, and the teachers' delivery during online class $(87.6 \%)$. These findings suggest that face-to-face interaction was still favorable, hence blended learning is seen to be a better option in learning science.
\end{abstract}

Keywords—science learning, online learning, meaningfull learning, covid-19

\section{INTRODUCTION}

The impact of the 2019 Coronavirus Disease pandemic (Covid-19) is drastically affect the education world. Most educational institutions do not carry out activities as usual; in order to reduce the spread of Covid-19 [1]. Various countries, including Indonesia have applied lockdowns or quarantine policies in place to reduce the interaction of too many people that may facilitate the spread of Covid-19.

In Indonesia, the number of positive Covid-19 patients per Thursday (05/28/2020), increased to 24.538 people [2]. A total of 1.496 of them died, and 6.240 people were declared cured. The cases came from DKI Jakarta (7.001), East Java (4.313), West Java (2.181), South Sulawesi (1.427), Central Java (1.336), South Sumatra (942), Banten (831), South Kalimantan ( 819), Papua (584), West Nusa Tenggara (562), West Sumatra (541), Bali (420), North Sumatra (362), Central Kalimantan (337), North Sulawesi (297), East Kalimantan (281), Southeast Sulawesi (240), DIY (228), Maluku (188), West Kalimantan (184), Riau Islands (175), North Kalimantan (165), West Papua (152), North Maluku (128), Central Sulawesi (126) ), Lampung (118), Riau (111), Jambi (97), West Sulawesi (88), East Nusa Tenggara (85), Bengkulu (71), Gorontalo (65).

Based on data obtained from UNESCO, more than 160 countries have implemented national lockdowns. The latest statistics from UNESCO (03/25/2020) stated that 1.524.648.768 students were affected by the COVID-19 virus from $87.1 \%$ of the total students enrolled. So far India and China are the countries with the largest number of COVID-19 viruses, namely more than 270 million students, and in Indonesia as of Wednesday (03/25/2020) 68.265.787 students were affected by Covid-19 [3]. While other countries, 165 countries in Africa, Asia, Europe, the Middle East, North America and South America have announced or imposed restrictions on school and university learning. UNESCO provides direct support to various countries, including solutions for inclusive distance learning. UNESCO together with each 
country works together to ensure continuous learning for all, especially disadvantaged children and adolescents who tend to be hardest hit by school closures. The total number of students who are potentially at risk from pre-primary to high school education is $577.305,660$. On the other hands the number of students who are potentially at risk from higher education is 86.034.287 [3].

Currently in Indonesia, several universities have also conducted distance teaching and learning activities via online lectures. This is actually not a problem for universities that already have an online academic system. However, this can be a problem for universities that do not yet have an online academic system [1]. The Ministry of Education and Culture (Kemdikbud) is currently preparing different scenarios including setting up applications that facilitate online learning (in networks) for students. In an effort to keep students studying at home, such as an android-based distance learning application: "Portal Rumah Belajar" [4]. This portal can be accessed at learning.kemdikbud.go.id. Some interesting features that can be accessed by students and teachers include learning resources, digital classes, virtual laboratories, and question banks. The learning center can be utilized by students and teachers of Early Childhood Education, Elementary Schools, Junior High Schools, High Schools, or Vocational Schools or equivalent.

Additionally, the Ministry of Education and Culture has joint seven online learning platforms namely Smart Classes, Quipper, Google Indonesia, Sekolahmu, Zenius, and Microsoft. Each platform will provide facilities that are publicly accessible and free. Several online learning platforms that can be accessed by students and teachers to improve learning resources include Google Indonesia, School, Smart Classes, Zenius, Quipper, and Microsoft [4]. Although many platforms have been introduced to teachers to perform quality online learning, reports on the utilizations of this available platforms and its effectiveness are not widely available. Therefore, this study aims at analyzing the use of online learning platforms and its effectiveness in delivering science learning. Additionally, students' responses on science learning via online platforms are also recorded and analyzed.

\section{MethodS}

This research is a qualitative research with a case study approach. This study was designed by focusing on extracting information on the implementation of online learning in Natural Sciences (IPA) subjects at the level of junior high school/equivalent. The purpose of this study is to (1) get a description of how junior high school students/equivalent learn of natural science in online learning carried out by their teacher, (2) get a description of the difficulty of student learning in online science learning, and (3) get an overview of teacher understanding and implementation of the letter Circular of the Minister of Education and Culture of the Republic of Indonesia on 4 points of distance learning by teachers in online science learning in the middle of the COVID-19 pandemic.
The instrument in this case study research used a questionnaire. Research informants are subjects who understand the object of research information as actors as well as others who understand the object of research $[5,6]$. Respondents consisted of 97 students from 7 junior high schools/equivalent who carried out online science learning at home and 10 teachers who were spread out in the same 7 schools. This case study research uses 2 kinds of questionnaires, namely Student's Questionnaire and Teacher's Questionnaire.

Student questionnaire was made to find out how junior high school students learn science in online learning carried out by their teacher and to find out student learning difficulties. The teacher questionnaire was made by referring to the Circular of Minister of Education and Culture number 4 of 2020 regarding the Implementation of Education Policy in the Emergency Period of the Spreading of Coronavirus Disease 2019 (Covid19). The Minister of Education and Culture explains the rules in more detail about points of distance learning [7]. This questionnaire was created to measure the understanding and implementation of 4 points of distance learning by teachers in online science learning in the middle of the Covid-19 Pandemic. The data analysis technique used in this research is descriptive analysis technique that is by describing the results of case studies descriptively.

\section{RESULTS AND DISCUSSION}

The research began by creating an online questionnaire instrument through the Google Form application. This questionnaire was created to find out how junior high school students learn science in online learning carried out by their teacher and to find out student learning difficulties. Online learning is done because of the growing corona virus outbreak. For the sake of breaking the chain of the spread of the corona virus due to exposure from one human to another so that faceto-face learning in class or at school is canceled or closed down to be replaced by online learning from their homes.

Based on the results of a questionnaire 97 respondents $(100 \%)$ answered teachers using the Whatsapp Group application in online science learning and $100 \%$ of students did it at home (as recommended for work from home, learn from home and physical distancing). The Whatsapp application is downloaded on their mobile phones and they are online in learning prepared by teachers through their mobile phones not through laptops. Whatsapp was chosen because this application is very familiar to every class of society including students and teachers of junior high school/equivalent so that it is easy to use, available on a mobile phone so that it is very mobile, not constrained by time and place, has the facility to send text messages, Microsoft Word files, Excel, PowerPoint, PDF, image/photo, sound, videos and all files are automatically saved in whatsapp which can be accessed at any time [8-11]. Whereas for internet access, 48 respondents or $49 \%$ answered using the internet data package quota on their own cellphones and the remaining $51 \%$ answered using wifi. Based on the results of the questionnaire that 81 respondents or $85 \%$ 
answered the internet signal smoothly during online learning, and not smoothly (weak or no signal) $15 \%$.

The results on activities of teachers in online learning are given by the graph in Figure 1. It appears that learning by the teacher is dominated by the teacher explaining the material and giving assignments to do the questions. More assignments (93.8\%) compared to teaching $(44.3 \%)$.

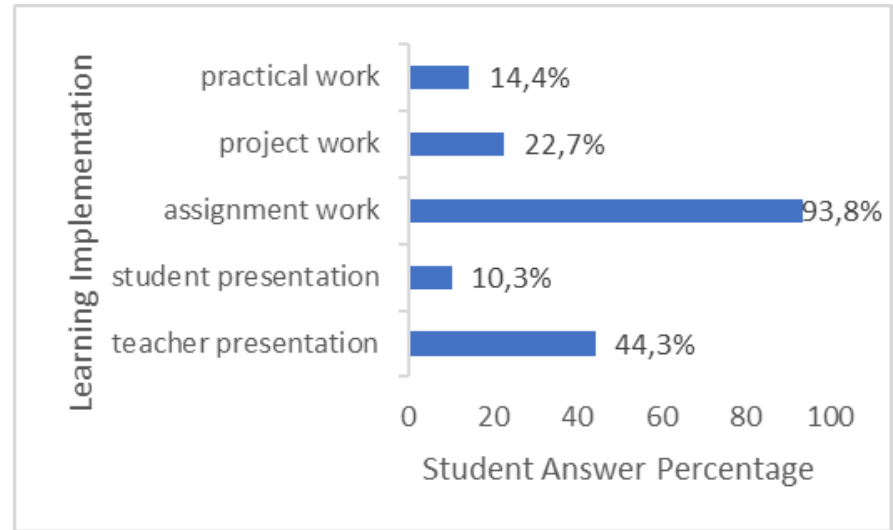

Fig. 1. Chart of teacher activities in online science learning.

97.9\% of the assignments given by science teachers in online learning are still dominated by multiple choice questions. See Figure 2 below.

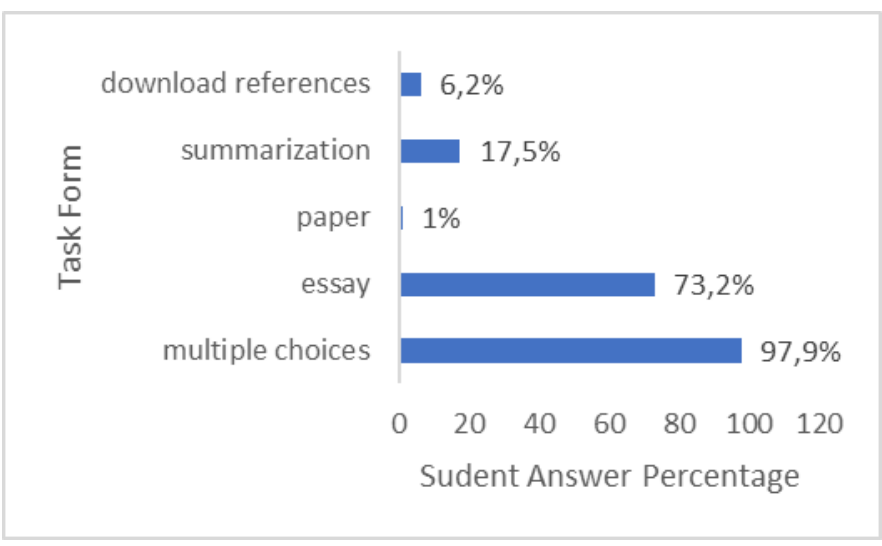

Fig. 2. The form of assignments given by science teachers in online learning.

Another thing obtained about how students learn science online is that $88.7 \%$ of online science learning effectively makes students active in learning. $91.8 \%$ of online science learning is considered beneficial for students. $59.8 \%$ of students like to take part in science learning that is done online. The teacher still has not given project assignments in the form of product items either for individual or group assignments. $91.8 \%$ of online science learning is still not given in the form of practical work done by students at home.

The Minister of Education and Culture of the Republic of Indonesia (Mendikbud) said as reported in the online media kompas.com and CalderaNews.com that distance learning in the network carried out at home requires teachers to be creative in giving material, not to burden students with multiple assignments (homework) thus making students more stressed while studying at home which has an impact on the immune (immunity) of the student's body decreases and in the end easily infected or infected with covid-19 virus [12-16]. This is what we must avoid. From the results of the questionnaire about $93.8 \%$ of teachers gave assignments (homework) and students worked on assignments/homework/questions. Tend to still conventional/classic tasks $(97.9 \%$ multiple choice questions). This condition must be improved to better provide interesting learning and innovative assignments.

Teachers or schools must turn to the concept of learning that does not only focus on academic or cognitive, adjust the assessment mode that will replace the national exam (Ujian Nasional), namely Competency Assessment and Character Survey. The Competency Assessment and Character Survey focus more on reasoning and not the achievement of subject matter understanding. Competencies close to science in accordance with the nature of science are science process skills and inquiry skills, one of which can be taught/provided/trained with students doing practical work $[17,18]$. Based on the results of the questionnaire, there were only a few teachers asking students to do practical work at home, only $8.2 \%$ was obtained.

Description of the learning difficulties of junior high school/equivalent students in meaningful online science learning in 7 junior high school/equivalent in Singkawang City during the Covid-19 pandemic period are:

- $69.1 \%$ of students find it difficult to understand the science subject matter that is done online.

- $61.9 \%$ of students have difficulty in doing the task of science subjects done online.

- $57.7 \%$ internet quota of student mobile is not always available.

- $87.6 \%$ of students preferred the teaching style of natural science teachers in non-online classes (face-to-face classes) compared to online classes (dislike online).

- $78.4 \%$ of students said it was better for science learning to be done face-to-face in the classroom at school than online at home. $78.4 \%$ of students said it was better for science learning to be done face-to-face in the classroom at school than online at home, meaning that the majority of students would prefer to study at school if the school was opened. This is consistent with Marzano's (1985) and Bruner's (1960) learning theory about the balance of the realm of attitudes, skills and knowledge at the elementary, junior high, high school, and higher education levels that composition of junior high school students is dominated by the formation of attitudes or characters that appear to the eye so that they must manifested real by students and physically observed by the teacher [19-22]. In online learning the 
teacher is difficult to shape student attitudes and measure them. Finally, online learning is dominated by knowledge content. Then the age of junior high school students is the age where learning independence has not yet been formed so that in online learning students will experience difficulties where in online learning students are required to be independent. As a result students find it difficult to understand the subject matter because they still need to get guidance on their learning process and cannot be fully independent.

- $70.1 \%$ of students have difficulty interacting with teachers by saying online science learning makes us more distant from the teacher.

- $73.2 \%$ of students said they were getting away with their peers.

Through the Minister of Education and Culture's Circular Letter number 4 of 2020 regarding the Implementation of Education Policy in the Emergency Period of the Spread of Coronavirus Disease (Covid-2019), the Minister of Education and Culture explains the rules in more detail on the points of distance learning [7]. In point 2 of the circular explained, the Learning Process from Home is carried out with the following conditions:

- Learning from Home through online/distance learning is carried out to provide meaningful learning experiences for students, without being burdened with the demands of completing all curriculum achievements for grade and graduation graduation. From the results of the questionnaire, the teacher's activities seemed to pursue curriculum achievements, however, $80 \%$ of the teachers had set up learning by the way students linked the new information they received (teaching material) to the concepts students had. $90 \%$ of teachers have taught concepts from more general to specific. $90 \%$ of teachers have presented new subject matter, done by linking the material with relevant concepts that already exist in students' cognitive structures. $100 \%$ of the teachers have set up learning by means of students discovering their own concepts and the teacher as a facilitator It appears from the results of the questionnaire above the teacher has applied meaningful learning in online science to students (with an average indicator greater than or equal to $80 \%$ met). This result is in line with Ausubel Learning Theory. Learning meaningfully, individuals must connect new knowledge with relevant concepts they already know. New knowledge must interact with the student's knowledge structure. Knowledge is arranged hierarchically; that new information is meaningful insofar as it can be linked (attached, anchored) to what is already known [18]. Meaningful learning is a learning process where new information is linked to the understanding structure that is already possessed by a person who is in the learning process. Learning means trying to explain the relationship or relevance of new materials with old materials, first giving the most general ideas then things that are more detailed, showing similarities and differences between new materials and old materials, making sure that existing ideas are mastered completely before a new idea is presented [18]. Meaningful learning is a process of linking new information to relevant concepts contained in a person's cognitive structure. Cognitive structures are facts, concepts and generalizations that students have learned and remembered [18]. make sure that existing ideas are fully mastered before new ideas are presented [18]. Meaningful learning is a process of linking new information to relevant concepts contained in a person's cognitive structure. Cognitive structures are facts, concepts and generalizations that students have learned and remembered [18]. make sure that existing ideas are fully mastered before new ideas are presented [18]. Meaningful learning is a process of linking new information to relevant concepts contained in a person's cognitive structure. Cognitive structures are facts, concepts and generalizations that students have learned and remembered [18].

- Learning from home can be focused on life skills education including the Covid-19 pandemic. Based on the results of the questionnaire most students already know how to prevent the spread / outbreak of Covid-19, namely by diligently washing hands with soap and running water (42.2\%), staying at home (34.4\%), physical distancing $(15.6 \%)$ and using a mask (7.8\%).

- Learning activities and assignments Learning from home can vary between students, according to their interests and conditions, including considering the gap of access / learning facilities at home. From the results of the questionnaire, it was impressed that the students' assignments were still monotonous, dominated by multiple choice questions of $97.9 \%$, however on the other hand it was found that $50 \%$ of the teachers gave assignments for students to choose freely according to the interests and conditions of each student. The various forms of assignments or activities given by the teacher to their students are:

○ the task of making learning posters or videos.

○ the task of making a life skills practice video in the midst of the Covid-19 pandemic such as washing hands properly, wearing masks and procedures or ethics in sneezing and coughing.

o the task of making a video tutorial on making herbal concoctions to enhance immunity.

o the task of making a WHO standard hand-sanitizer video tutorial.

○ assignments according to students' interests and talents such as poetry music videos about the struggle of the vanguard and others. 
- Evidence or products from Home Learning activities are given qualitative and useful feedback from the teacher, without being required to give quantitative scores. $60 \%$ of teachers still have not provided qualitative feedback on student work outcomes or evidence of student learning activities from home. Feedback can be given during the learning process and can also be in the form of giving tests/quizzes. Because only $46.9 \%$ of the teachers gave explanations of the material and feedback questions online in the WhatsApp group, only that teacher and in the class had a feedback process (a percentage was still small). While based on the results of the questionnaire, the teacher gives a task/quiz with $50 \%$ of students answering there is a test/quiz, meaning that only the teacher and in the class there is feedback on the answers of the test/quiz students.

Teachers are expected to realize meaningful education at home. Meaningful learning is not only focused on academic or cognitive achievement, but also emphasizes the development of "life skills" and character. For life skills education, teachers and parents can make the activity of understanding the Covid19 pandemic as learning material. Starting from an explanation of the virus to preventative measures such as washing hands and using masks. That way, children have insight about what is happening around them and are able to protect themselves. Teachers are encouraged to guide students not only to give them homework. The teacher carries the mandate of Law No.20 of 2003 concerning the national education system that the goal of Indonesia's national education is to develop the potential of students to become people of faith and to devote to God Almighty, of good morality, healthy, knowledgeable, capable, creative, independent, and be a democratic and responsible citizen. The teacher also has duties according to Law No. 14 of 2005 concerning Teachers and Lecturers that the Teacher is a professional educator with the main task of educating, teaching, guiding, directing, training, evaluating, and evaluating students in early childhood education through formal education, basic education, and secondary education.

Meaningful learning when learning from home can be done one of them by providing the teaching material that is not only focused on academic or cognitive achievements, but also which gives new meaning, including understanding the Covid-19 pandemic. As reported in the media kalderaNews.com, that Minister of Education and Culture of Republic Indonesia: $\mathrm{Mr}$. Nadiem Anwar Makarim, appealed for learning activities both in schools and colleges in areas affected by Coronavirus Disease (Covid-19) to be carried out at home. Educators and education personnel also do not need to come to school or campus for a while. The learning process or completion of administrative affairs can continue to run by utilizing technology [12-16].

From the results of the student questionnaire it appears that all students (100\%) adhere to online learning at home (not outside the home, not online at cafes, coffee shops or at internet cafes). Online students use their own mobile phones so that it is flexible and makes it easy to follow online science learning using the whatsapp application (100\% of students answer using whatsapp). What we want together (government, school, parents, community) is achieved for students to study at home in order to reduce the spread of Covid-19 by physical distancing (avoiding contact/physical contact or maintaining physical distance, reducing the mobility of people from one place to another place and reduce the crowd).

\section{CONCLUSIONS}

Online science learning is still dominated by the use of WhatsApp as a tool and learning media of $97.9 \%$. Learning is still dominated by assignments of multiple-choice questions, even though it still can make students active $88.7 \%$; students were happy even though a small percentage $(59.8 \%)$ and felt useful by students $91.8 \%$. Difficulties faced by students when learning online are students having difficulty understanding the material (69.1\%); students find it difficult to work on assignments $(61.9 \%)$; students do not always have internet quota on their mobile phones $(57.7 \%)$, students do not like the teaching style of teachers $(87.6 \%)$, students have difficulty interacting with teachers which causes students to get further away with teachers (70.1\%) and students farther away with his friends $(73.2 \%)$. The teacher has applied meaningful learning in online science learning to students (with an average indicator of more than $90 \%$ being met). The teacher has provided Covid19 prevention life skills $(90 \%)$. The teacher has provided diverse activities through various assignments that are freely chosen by students according to the interests and conditions of each student (although still in a small percentage only 50\%). The teacher still has not provided qualitative feedback on the results of student assignments or evidence of student learning activities from home $(60 \%)$.

\section{ACKNOWLEDGMENT}

Acknowledgments are given to Lembaga Pengelola Dana Pendidikan (LPDP) Kementerian Keuangan Republik Indonesia for scholarship, research and publication costs with the contract number: KET-575/LPDP.4/2020.

\section{REFERENCES}

[1] A. Abidah, H.N. Hidaayatullaah, R.M. Simamora, D. Fehabutar, and L. Mutakinati, "The Impact of Covid-19 to Indonesian Education and Its Relation to the Philosophy of 'Merdeka Belajar'," Studies in Philosophy of Science and Education, vol. 1, no. 1, pp. 38-49, 2020.

[2] Covid19.go.id. Situasi Virus Corona, 2020. [Online] Retrieved from: https://www.covid19.go.id/situasi-virus-corona/

[3] UNESCO, Education Emergencies, 2020. [Online] Retrieved from: https://en.unesco.org/themes/education-emergencies/coronavirus-schoolclosures

[4] Kemdikbud, Cegah sebaran Covid19 di satuan pendidikan, Kemendikbud gandeng swasta siapkan solusi belajar daring, 2020. [Online] Retrieved from: https://www.kemdikbud.go.id/main/blog/2020/03/cegah-sebarancovid19-di-satuan-pendidikan-kemendikbud-gandeng-swasta-siapkansolusi-belajar-darin 
[5] J.W. Creswell and V.L.P. Clark, Educational Research Planning, Conducting, and Evaluating Quantitative and Qualitative Research, New Jersey: Pearson Prentice Hall, 2010.

[6] R.K. Yin, Case Study Research Design and Methods, Washington: COSMOS Corporation, 2011

[7] Mendikbud. Surat Edaran Nomor 4 Tahun 2020 Tentang Pelaksanaan Kebijakan Pendidikan dalam Masa Darurat Penyebaran Coronavirus Disease 2019, 2020.

[8] A. Prajana, "Pemanfaatan Aplikasi Whatsapp dalam Media Pembelajaran di UIN Ar-Raniry Banda Aceh," Cyberspace: Jurnal Pendidikan Teknologi Informasi, vol. 1, no. 2, pp. 122-133, 2017.

[9] I.M. Pustikayasa, "Grup WhatsApp Sebagai Media Pembelajaran," Widya Genitri: Jurnal Ilmiah Pendidikan, Agama dan Kebudayaan Hindu, vol. 10, no. 2, pp. 53-62, 2019.

[10] R. Iskandar, "Penggunaan Grup Whatsapp sebagai Media Pembelajaran terhadap Peserta Didik DTA At-Tawakal Kota Bandung," Comm-Edu (Community Education Journal) vol. 3, no. 2, pp. 97-101, 2020.

[11] H. Mu'alimah and I. Ishafit, "Pembelajaran inkuiri kolaboratif daring dengan media social Whats App pada kemampuan komunikasi terhadap materi kalor bagi peserta didik di abad 21," In Prosiding SNPF (Seminar Nasional Pendidikan Fisika), pp. 200-205, 2017.

[12] J.S. Britto, Siswa-Mahasiswa Belajar di Rumah, Mendikbud: PendidikPegawai Harus Bekerja dari Rumah, Jakarta: Kaldera News, 2020. [Online] Retrieved from: (http://www.kalderanews.com/2020/03/siswamahasiswa-belajar-di-rumah-mendikbud-pendidik-pegawai-harusbekerja-dari-rumah/).

[13] A.P. Kasih, Belajar di Rumah Diperpanjang, Kemendikbud: Berikan Materi Life Skills dan Karakter, Jakarta: Kompas News, 2020. [Online] Retrieved from: https://edukasi.kompas.com/read/2020/03/27/142507671/belajar-di- rumah-diperpanjang-kemendikbud-berikan-materi-life-skilldan?page $=$ all.

[14] Malena, Guru wajib sisipkan edukasi Covid-19, Jakarta: Kaldera News, 2020. [Online] Retrieved from: https://www.kalderanews.com/2020/03/guru-wajib-sisipkan-edukasicovid-19-saat-belajar-daring/.

[15] Malena, Ini 7 Permintaan Jokowi untuk Percepatan Penanganan Virus Corona, Jakarta: Kaldera News, 2020. [Online] Retrieved from: http://www.kalderanews.com/2020/03/ini-7-permintaan-jokowi-untukpercepatan-penanganan-virus-corona/.

[16] R.S. Nugroho, Corona: 421 juta pelajar di 39 negara belajar di rumah, kampus di Indonesia Kuliah Online, 2020. [Online] Retrieved from:, https://www.kompas.com/tren/read/2020/03/14/120000765/corona-421juta-pelajar-di-39-negara-belajar-di-rumah-kampus-di-indonesia.

[17] A. Lepiyanto, "Analisis keterampilan proses sains pada pembelajaran berbasis praktikum,” BIOEDUKASI, vol. 5, no. 2, pp. 156-161, 2017.

[18] Suparno, Teori Belajar Konsep dan Strategi Penerapannya di Kelas, Jakarta: Rineka Cipta, 2010.

[19] R.J. Marzano, B. Carbaugh, A. Rutherford, and M.D. Toth, "Marzano center teacher observation protocol for the 2014 Marzano teacher evaluation model," Palm Beach Gardens, Florida: Marzano Center/Learning Sciences International, 2013.

[20] R.J. Marzano, D. Pickering, and J.E. Pollock, "Classroom instruction that works: Research-based strategies for increasing student achievement," Ascd, 2001.

[21] J. Bruner, "Jerome Bruner: Reflections of a developmental psychologist," Human Development, vol. 51, no. 1, pp. 101-103, 2008.

[22] J. Bruner, In Search of Pedagogy Volume I: The Selected Works of Jerome Bruner, 1957-1978. Routledge, 2006. 